\title{
Proposal of a new method for effectiveness evaluation in the product design and development process
}

\author{
Adherbal Caminada Nettoa,*, Paulo Carlos Kaminski ${ }^{\mathrm{b}}$ \\ a,*adherbal@usp.br, EPUSP, Brazil \\ bpckamins@usp.br, EPUSP, Brazil
}

\begin{abstract}
This paper addresses the subject of product design process evaluation from the designer's point of view. Based on the results of a preliminary research phase a comprehensive questionnaire is drawn up, and applied to a selected group of designers in the automotive industry, comprising Brazilian plants of two major car manufacturers, two Tier 1 suppliers and one lorry and bus manufacturer. Data provided by the answers are compiled, presented and discussed within each organizational environment. A combined analysis is then carried out in order to identify those management actions that are considered by the automotive industry as being more important for both assuring and evaluating the effectiveness of the product design and development process. Management actions are classified according to criteria supplied by the ISO quality management standards. Finally, based on the evaluation, management action indicators are defined and a single and flexible effectiveness index is proposed, which can be calculated using both company and industry data for evaluation and benchmark purposes.
\end{abstract}

Keywords

Continual improvement. Critical incident technique. Effectiveness. Product design and development. ServQual.

\section{Introduction}

"An appropriate answer to the right problem is worth a good deal more than an exact answer to an approximate problem" John Wilder Tukey (UMM, 2005).

It should be considered that there are two aspects involved in the performance of design: the product that is being designed and the required development/design process. That is, both product design goals and development/design process goals exist and must be distinguished, considered and furthermore related to the overall performance of design. As pointed out by O'Donnel and Duffy (2002, p. 1203) the

[...] design goals relate to aspects of the design (artefact), such as functionality, form, or behaviour, while design activities goals relate to the activities in design development and consider aspects such as the time taken and cost of resources.

Being designers themselves, in previous papers Caminada Netto and Kaminski (2006; 2007) have expressed their concern about the adequacy of evaluation methods used for assessing the effectiveness of product design and development processes, and have justified their choice of a particular approach based on the designers' point of view as necessary to take into consideration two relevant aspects of design realization and evaluation. On the one hand, quality standards such as ISO 9001 (INTERNATIONAL..., 2008) simply do not require that the designers' point of view be formally taken into account when evaluating the quality and effectiveness of the product design process. On the other hand, the designer is certainly what authors like Latour (1994) might call a "central actor of the socio-technical network" of product realization.

Therefore, when "listening to what designers have to say", in addition to gathering meaningful information, one avoids an important evaluation drawback: the lack of formal measures of satisfaction in the appraisal process at the designer level of the organization. As mentioned by Thomson et al. 
(2003) the designers, as one of the stake holders of the product development process, are those who determine the functional, physical and symbolic product characteristics that are necessary to achieve customer satisfaction.

The objective of this work is basically to identify, employing well established methods in the fields of quality engineering and management, those factors that, from the designers' point of view, are deemed important to enable a given organization to assure and assess its capacity to continually improve the effectiveness of the design process.

It should be pointed out that the proposed method comprises two phases of research work, both involving the opinion of designers: preliminary research and research proper. Since the preliminary research has already been extensively described in one of the aforementioned previous papers (CAMINADA NETTO; KAMINSKI, 2006), only a brief description of this phase will be made, leading to the introduction of the central concept of effectiveness factor.

Concerning the research in the second phase, it will be described how a questionnaire based on the results of the preliminary phase was drawn up and applied to selected groups of college degree designers, as well as how data provided by the answers to this questionnaire were compiled, presented and discussed within each organizational environment.

A combined analysis will then be carried out in order to identify those assurance and evaluation management actions that are considered as being more important for both assuring and evaluating the effectiveness of the product design/development process. Finally, based on the evaluation, management actions indicators will be defined and a single and flexible effectiveness index proposed, which can be calculated using both company and industry data for evaluation and benchmark purposes.

The proposed method for effectiveness evaluation in the product design/development process was validated and will be exemplified in this paper by its application to the automotive industry, more specifically to five large companies in that industry in Brazil: two automobile manufacturers; two first tier suppliers; and one lorry manufacturer.

The authors are aware that this proposed method takes into consideration the designers' point of view only, and do not purport it to be complete. On the contrary, hope that it will be used as a contribution to broader methods that take into consideration, as much as possible, the opinions of all stake holders involved. However, the authors do believe that this method might also be employed with a fair chance of success to obtain such other interested parties' opinions.

\section{Brief description of the preliminary phase}

An exploratory survey constituted the first phase in assessing the designer's opinion as regards the evaluation of the effectiveness of the product design process. That phase employed a combination of the Critical Incident Technique (FLANAGAN, 1954; HAYES, 1998) and ServQual (PARASURAMAN; ZEITHAML; BERRY, 1990) approaches as follows:

- A Critical Incident Technique (CIT) questionnaire was drawn up;

- A unique and very representative population of designers was selected;

- Critical incidents were collected;

- Satisfaction items for product design and development were identified as shown in Chart 1; and

- Critical incidents were classified according to satisfaction items.

The reason for establishing the aforementioned connection between product design/development process satisfaction items and ServQual dimensions is that despite the fact that it contains a high amount of software, and sometimes varying amounts of other product categories, design is basically a service supplied to either internal or external customers.

Once the preceding steps had been completed, the affinity diagram technique (NAYATANl et al., 1994; MIZUNO; 1988) was used in order to translate the previous satisfaction items into the following six effectiveness factors capable of representing the effectiveness needs in the product design/ development process:

- Design preparation;

- Organizational environment;

- Information and knowledge;

- Technical personnel;

- Design realization;

- Product success.

Chart 1. Satisfaction items vs. ServQual dimensions.

\begin{tabular}{|c|c|c|}
\hline Product design & \multicolumn{2}{|c|}{ Service quality dimensions } \\
\hline Satisfaction item & Consolidated & Original \\
\hline $\begin{array}{c}\text { Documents } \\
\text { Resources }\end{array}$ & Tangibles & Tangibles \\
\hline $\begin{array}{c}\text { Fundamentals } \\
\text { Realization } \\
\text { Results }\end{array}$ & Reliability & Reliability \\
\hline $\begin{array}{c}\text { Plans } \\
\text { Budget }\end{array}$ & Responsiveness & Responsiveness \\
\hline $\begin{array}{c}\text { Competence } \\
\text { Experience } \\
\text { Information }\end{array}$ & Assurance & $\begin{array}{c}\text { Competence } \\
\text { Courtesy } \\
\text { Credibility } \\
\text { Security }\end{array}$ \\
\hline $\begin{array}{c}\text { Communication } \\
\text { Motivation }\end{array}$ & Empathy & $\begin{array}{c}\text { Access } \\
\text { Communication } \\
\text { Understanding the } \\
\text { customer }\end{array}$ \\
\hline
\end{tabular}


Figure 1, adapted from Caminada Netto and Kaminski (2006), exemplifies for the effectiveness factor "Design realization" the chain leading from critical incidents to effectiveness factors.

It should be pointed out that the affinity diagram or KJ method, originally developed at the Kawayoshida Research Centre in Japan, is perhaps the only quality technique dealing with intuition rather than logic. It is appropriate to be used for instance when (MIZUNO, 1988): "Facts are uncertain and hard to understand; they need to be grasped systematically. Thoughts are uncertain and disorganized; they need to be arranged."

Once having realized how ServQual dimensions, satisfaction items and effectiveness factors are closely interrelated, the authors observed that the latter constituted adequate building blocks for structuring an in-depth questionnaire aimed at assessing the effectiveness of the product design/ development process.

In other words, effectiveness factors constitute an important concept that allows one to link the opinion of a designer - a central actor of the socio-technical network (LATOUR, 1994) of product realization to the formal activities of effectiveness evaluation in the implementation of an organization's Quality Management System.

This paper addresses the second phase of the research, whose aim was to proceed from effectiveness factors to practical measures of process evaluation. With the completion of this second phase, it is hoped that another stone has been placed to pave the way to a 'friendlier' method of evaluating the process of product design, and one which may actually be found useful by designers and design organizations alike.

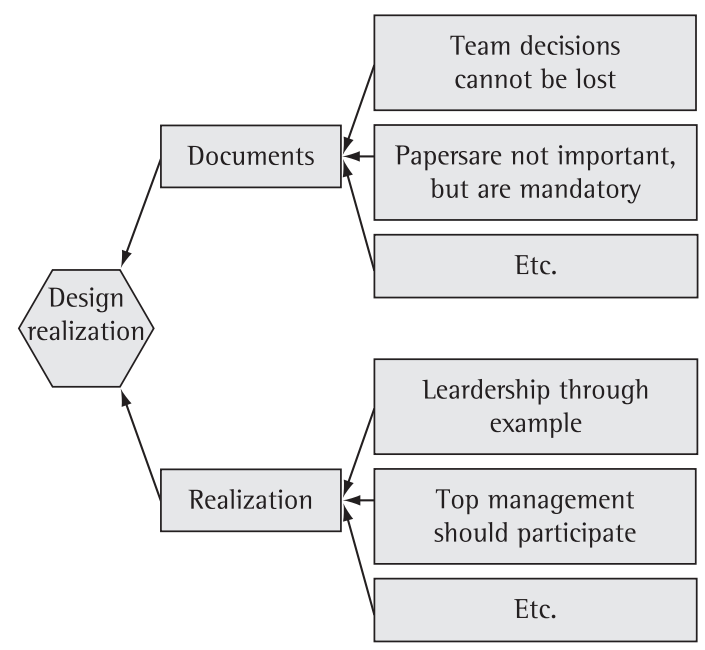

Figure 1. Critical incidents, satisfaction items and effectiveness factors.

\section{Research questionnaire}

The first step required to proceed from effectiveness factors to the product design/development process evaluation in the second phase of the research work was to draw up an understandable questionnaire, and then to apply it to selected groups of designers in the respondent organizations that had kindly agreed to cooperate with the authors' research.

The elaboration of any research questionnaire is a constant struggle between conflicting aspects such as concision and understanding, concision and clarification, simplicity and rigour, etc. The basic idea in this case was to present a logical sequence of design development to respondents, that is, to make each section of the final questionnaire refer to one of the effectiveness factors that had been developed by affinity grouping in the first phase, as illustrated in Chart 2 (CAMINADA NETTO; KAMINSKI, 2007).

As to the number and content of the questions, they had to be kept as concise as possible and at the same time adequately cover the respective satisfaction items shown in Chart 3 in their relation to both ServQual dimensions and effectiveness factors.

Once completed, the resulting questionnaire was kindly pre-tested by six designers at the Naval Centre of Technology in São Paulo, Brazil, with experiences ranging from 14 to 30 years in design activities. This pre-test proved to be very important, not only due to the meaningful alterations suggested by designers, but mainly because it allowed the authors to counterbalance a bias relating to the relative importance of design experience that had been detected in the first phase, in which respondents were designers predominantly in their late twenties and early thirties. An example, for the "Design Realization" block is showed in the Appendix.

\section{Respondent organizations}

The first set of questionnaires was applied in one of the factories of an automobile manufacturer that henceforth will be called Manufacturer A, to a group of college degree designers who had agreed to collaborate with the research.

Chart 2. Questionnaire contents.

\begin{tabular}{|c|c|}
\hline Section & $\begin{array}{c}\text { Evaluation of aspects } \\
\text { relating to }\end{array}$ \\
\hline Introduction & Purpose and instructions \\
\hline Design preparation & Resources, plans and budget \\
\hline Organizational environment & Communication and motivation \\
\hline Information and knowledge & Foundation and information \\
\hline Technical personnel & Competence and experience \\
\hline Design realization & Documents and realization \\
\hline Product success & Results \\
\hline The word is yours & Opinions and comments \\
\hline Personal data & Demographic information \\
\hline
\end{tabular}


Chart 3. Dimensions, satisfaction items and effectiveness factors.

\begin{tabular}{|c|c|c|c|c|c|c|}
\hline $\begin{array}{r}\text { Effectiveness } \\
\text { factors }\end{array}$ & $\begin{array}{c}\text { Design } \\
\text { preparation }\end{array}$ & $\begin{array}{c}\text { Organizational } \\
\text { environment }\end{array}$ & $\begin{array}{c}\text { Information } \\
\text { and knowledge }\end{array}$ & $\begin{array}{c}\text { Technical } \\
\text { personnel }\end{array}$ & $\begin{array}{c}\text { Design } \\
\text { realization }\end{array}$ & $\begin{array}{c}\text { Product } \\
\text { success }\end{array}$ \\
\hline Tangibility & Resources & & Fundamentals & Documents & Realization & Results \\
\hline Reliability & Plans budget & & Information & $\begin{array}{c}\text { Competence } \\
\text { experience }\end{array}$ & & \\
\hline Assurance & & & & & & \\
\hline Empathy & & $\begin{array}{c}\text { Communication } \\
\text { motivation }\end{array}$ & & & & \\
\hline
\end{tabular}

A second set was applied in the Department of Mechanical Engineering of the Engineering College at the University of São Paulo, to a group of designers enrolled in the Automotive Masters Degree Program and working for another automobile manufacturer that henceforth will be called Manufacturer B.

Considering the positive experience with the aforementioned groups, as well as the desire to increase the scope of the research, it was decided that the questionnaires would be applied to three other groups of college degree designers: one from a lorry manufacturer and two from so called "Tier 1 suppliers", i.e., suppliers that supply auto parts directly to the manufacturers. The lorry manufacturer will be henceforth referred to as manufacturer c, and the Tier 1 suppliers, respectively as supplier $\mathrm{x}$ and supplier $\mathrm{z}$.

Table 1 shows the number of individual respondents in each organization, and Table 2 presents a brief demographic description of these respondents, showing both age and experience in design activities. The average experience in design activities was 7.73 years.

\section{Analysis of results}

Individual answers, with grades ranging from 0 to 6 , were processed for each organization and results were represented graphically. Figures 2 and 3 constitute an example of such graphs and they refer to questionnaire section "Design Realization", as described in Chart 2, for Supplier X.

The overall average grade for the section illustrated in Figures 2 and 3 is 4.88. Data analysis reveals that in this section, statements $5,7,8,9$ e 10 show values higher than the overall average, with respectively standard deviation values of 0.85 , $0.71,0.71,0.69$ and 0.73 .

Statement 5 reveals concern with leadership and managerial competence and its high average grade agrees with what was also verified in questionnaire section IV, "Technical Staff". On the other hand statement 7 , that is a confirmatory statement,
Table 1. Number of individual respondents.

\begin{tabular}{ccc}
\hline Organization & Designed product & Quantity \\
\hline Manufacturer A & Automobiles & 14 \\
Manufacturer B & Automobiles & 24 \\
Manufacturer C & Lorries and buses & 14 \\
Supplier X & Auto parts & 19 \\
Supplier Z & Auto parts & 15 \\
\hline & Total & 86 \\
\hline
\end{tabular}

also matches the actual degree of concern about the compliance with the schedule for each design phase revealed in questionnaire section 1, "Design Preparation".

The average grade received by statement 8 indicates a high level of awareness as regards the need for design process assessment, either as a consequence of requirements posed by the systematic application of quality management systems standards, or due to a genuine understanding of the value of quality, and therefore of continual improvement for competitiveness.

The degree of importance attributed to statement 9 seems to confirm the familiarity of the respondent designers with quality management standards, revealing a perception of the importance of the establishment of authorities and responsibilities of design team members - accordingly eliminating lack of definitions and/or duplicities - in order to assure the adequate management of the design process.

On the other hand, the highest average grade received by statement 10 reveals an understanding of the importance of the programming of design activities - although programming has not yet been satisfactorily dealt with in management standards - in order to assure the effectiveness of the design process.

It is interesting to note that statement 4 has not obtained an especially high grade, which may reveal a limited interest for methodology selection since designers in the automotive industry are already used to employing proven methodologies such as the APQP (INSTITUTO..., 1997). 
Table 2. Demographic description of respondents. of college degree designers.

\begin{tabular}{|c|c|c|c|c|c|c|}
\hline \multirow{2}{*}{ Organization } & \multicolumn{3}{|c|}{ Age (years) } & \multicolumn{3}{|c|}{ Experience (years) } \\
\hline & Youngest & Oldest & Average & Lowest & Highest & Average \\
\hline Manufacturer A & 25 & 47 & 33.50 & 3 & 20 & 8.00 \\
\hline Manufacturer B & 25 & 43 & 32.25 & 1 & 18 & 7.30 \\
\hline Manufacturer C & 24 & 40 & 34.43 & 1 & 18 & 9.71 \\
\hline Supplier X & 22 & 46 & 33.11 & 2 & 18 & 7.11 \\
\hline Supplier Z & 27 & 43 & 35.47 & 1 & 19 & 7.73 \\
\hline
\end{tabular}

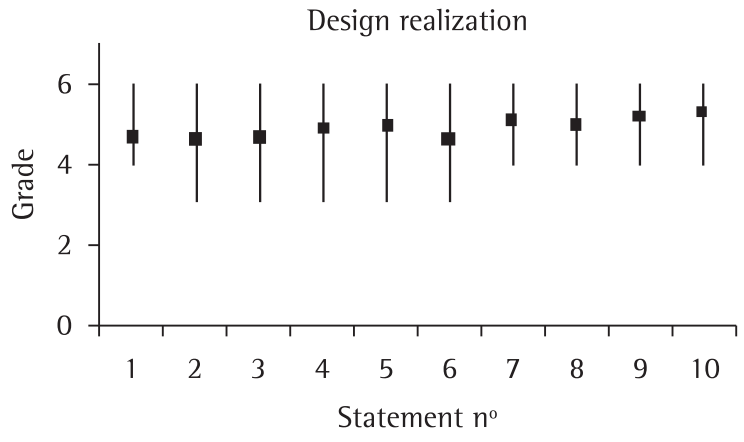

\begin{tabular}{|c|cccccccccc|}
\hline Statement No. & 1 & 2 & 3 & 4 & 5 & 6 & 7 & 8 & 9 & 10 \\
\hline Average grade & 4.68 & 4.63 & 4.68 & 4.84 & 4.95 & 4.63 & 5.05 & 4.95 & 5.16 & 5.26 \\
Standar Dev. & 0.67 & 0.83 & 0.82 & 1.01 & 0.85 & 0.83 & 0.71 & 0.71 & 0.69 & 0.73 \\
\hline
\end{tabular}

Figure 2. Supplier X. Highest, lowest and average grades for "Design Realization".

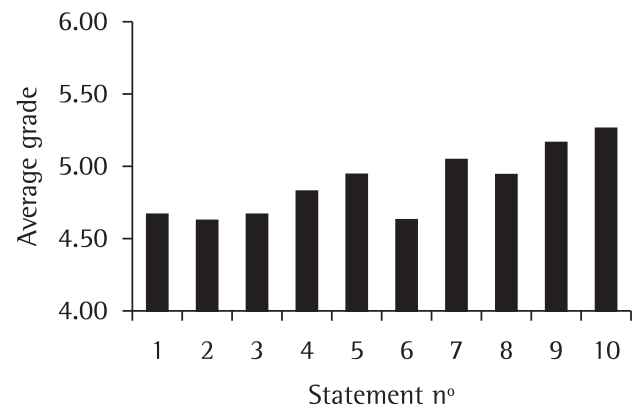

1. Comprehensive records of design history

2. Availability of data base for lessons learned

3. Standardization of all that can be standardized

(calculations, drawings, forms, etc.)

4. Use of specific design methodology

5. Involvement of top management in the design effort

6. Involvement of other areas within the organization in the design effort

7. Monitoring of completion dates for design phases

8. Monitoring of design success indicators or criteria

9. Establishment of authorities and responsibilities for

team members

10. Programming of design activities

Figure 3. Supplier X. Average grades for questionnaire section "Design Realization".
Results show that the main concerns expressed by designers in this questionnaire section can be summed up as:

- Programming and control of design activities;

- Establishment of authorities and responsibilities; and

- Involvement of top management in the design effort.

Similar graphs were drawn up and a qualitative analysis was also carried out for the other organizations and all questionnaire sections.

\section{Combined analysis}

Results were investigated for all questionnaire sections, summarized for each organization and then combined in tables such as Tables A. 1 and A.2 of the Appendix. Table A.1 shows, for each organization, the statements of the considered questionnaire section in descending order of average grade magnitudes, i.e., from highest $\left(1^{\text {st }}\right)$ to lowest $\left(10^{\text {th }}\right)$. It should be noted that statements with equal average grade values were ranked according to their respective number in the considered section. For instance, statements 1 and 9 for Manufacturer A were ranked as $2^{\text {nd }}$ and $3^{\text {rd }}$ respectively. 
Table A.2 shows the relative positions of each statement in the considered section according to the average grade values obtained in each organization. Here, however, statements with equal average grade values were placed in the same position. That is, in the case of statements 1 and 9 for Manufacturer A, both are placed in the $2^{\text {nd }}$ position. In addition, for the sake of simplicity, each organization is herein represented simply by the last letter of its name. Thus, Manufacturer A is represented by A, Manufacturer $B$ by B, and so forth.

The last three lines in Table A.2 also show the highest and lowest positions for each statement, as well as the relative position amplitude (RPA) as defined by the following equation:

$R P A=P_{\text {high }}-P_{\text {low }}$

where:

- $\mathrm{P}_{\text {high }}=$ highest relative position for the statement;

- $\mathrm{P}_{\text {low }}=$ lowest relative position for the statement.

As seen before, all 60 statements in the six questionnaire blocks were suggested by designers (other than those interviewed in this work) during the preliminary phase of the research, whose objective was no other than to allow the drawing up of a questionnaire that would be meaningful for all designers. The adherence of answers to this proposed objective can be assessed by means of a simple analysis, that is, by observing the following values:

- No statement had an average lower than 3.00;

- 299 statements $(299 / 300=99.67 \%)$ had averages greater than 3.50;

- 290 statements $(290 / 300=96.67 \%)$ had averages equal to or greater than 4.00;

- 257 statements $(257 / 300=85.67 \%)$ had averages equal to or greater than 4.50;

- 104 statements $(104 / 300=34.67 \%)$ had averages equal to or greater than 5.00 .

Such results seem to indicate that all statements, as expected, were perceived by the respondents as meaningful for the assessment of the design/ development process effectiveness. In this sense, it can be considered that the particular answer distribution, with a high frequency concentration at higher assessment values, stems from a deliberate bias, introduced in the questionnaire as a consequence of the results obtained in the preliminary exploratory phase. This is considered to be a specific and important aspect of the present work.

If, for each block corresponding to one of the effectiveness factors, the averages obtained by the respective statements in each of the organizations that participated in the research are added together to obtain a statement sum, and then if all statement sums are added in order to obtain a total average sum, one reaches the result exemplified in Table A.3 for the "Design preparation" block. It is possible now to calculate the variation coefficient $(\mathrm{VC})$ as defined in the following equation:

$V C=\frac{D P_{S b a}}{M_{S b a}}$

where:

- $\mathrm{M}_{\mathrm{Sba}}=$ average of total average sums;

- $\mathrm{DP}_{\mathrm{Sba}}=$ standard deviation of total average sums.

It can be seen in Table 3 (CAMINADA NETTO, 2006) that the difference between average sums for each block is very small, and that it is not really possible to establish priorities between effectiveness factors. Therefore, this equal importance attributed to the effectiveness factors seems to corroborate the adherence to the proposed objective of drawing up a questionnaire containing what is meaningful and important for assessing the effectiveness of the product design/development process.

Therefore, what seems to be important in this combined analysis is to identify the degree of agreement among designers in different organizations as regards the relative positions of the several statements. Particularly, if one intends to use the results in order to assess effectiveness, to identify those statements with both a high degree of agreement and relative importance, as suggested by the exam of RPA values in Table A.2.

In order to identify statements with the highest relative importance, an adaptation of the well known Nominal Group Technique (NGT) was employed. Proposed by Delbecq and Vande Ven in 1968, this widely used technique is described, either in its original form or in modified versions, in a considerably large number of bibliographical references. The reader may refer to E.U.A. (2006), ASQ (AMERICAN..., 2006), Taylor-Powell (2006), Michigan State University (2006), Dobbie et al. (2004) and Scholtes (1988), among others.

Thus, if each one of the organizations where the research was carried out is considered to be a component of a nominal group formed by individual organizations in the automotive industry, it is possible to arrive at a combined priority for each questionnaire statement by means of relative importance grades such as those indicated in Table A.4. It should be noted that this table is similar to Table A.2, with the following differences:

- In the left column, the classification from $1^{\text {st }}$ to $10^{\text {th }}$ was replaced, respectively, by grades from 10 to 1 ;

- The last three lines were replaced by two lines containing, respectively, the values for $\mathrm{S}_{\mathrm{j}}$ and the priority index $\mathrm{Pl}_{\mathrm{i}}$, related to each statement by the following equation: 
Table 3. Effectiveness factors: variation coefficient.

\begin{tabular}{cc}
\hline Effectiveness factor & Total average sum \\
\hline Design preparation & 241.55 \\
Organizational environment & 238.76 \\
Information and knowledge & 244.79 \\
Technical personnel & 241.38 \\
Design realization & 240.93 \\
Product success & 243.78 \\
$\mathrm{M}_{\text {sba }}$ & 241.87 \\
$\mathrm{Dp}_{\text {sba }}$ & 2.15 \\
$\mathrm{Cv}$ & 0.0089 \\
\hline
\end{tabular}

$$
P I_{j}=100 \cdot\left(\frac{S_{j}}{S_{T}}\right)
$$

where:

- $\mathrm{S}_{\mathrm{j}}=$ sum of grades obtained in different organizations by statement $\mathrm{j}$;

- $\mathrm{j}=1,2,3 \ldots 10$;

- $\mathrm{S}_{\mathrm{T}}=$ sum of grades for all statements.

As previously remarked, the application of the NGT allows one to identify statements with the highest relative importance. It remains necessary, however, to verify the degree of agreement among the involved organizations as regards the relative importance of each statement. In other words, it is necessary to discriminate between statements that can be considered as representative of a common or "industry" perception, and those representing the different concerns of individual organizations. It is believed that the priority index $\mathrm{Pl}_{\mathrm{j}}$, by taking into consideration the sum of grades obtained by each statement in different organizations, reflects both the relative importance and the degree of agreement among different individual organizations as regards such relative positions.

The practical utilization of the priority index, however, implies the choice of a criterion for the selection of those statements that will be considered as more important for the adoption of management actions. Bearing in mind that statements are compared within the framework of their respective questionnaire section, it was decided to consider the three statements with the highest $\mathrm{Pl}_{\mathrm{j}}$ in each section. Thus, as can be seen in Table A.4, it is possible to select statements whose $\mathrm{Pl}_{\mathrm{j}}$ stand out when compared to others within the same section, and at the same time to limit the number of indicators to an essential minimum. According to this criterion, Table A.5 shows those statements selected in each section for the adoption of management actions.

It is important to note that statements listed by questionnaire section in Table A.5 allow one to distinguish - when carrying out a joint analysis
- those statements that represent a common concern for the whole industry from those constituting contingent or even permanent specific aspects of each company. Table A.5, therefore, constitutes an important contribution of the present research, since it presents the most meaningful statements of the automotive sector as a whole.

\section{Continual improvement of the product design and development process}

\subsection{Proposed method}

The flow chart in Figure 4 provides an overall view of the present work, including both what has been described so far and additional points that will be dealt with in the following items.

Any one conversant with product design matters, when confronted with Table A.5, will concede that in common ad hoc meetings for the discussion of effectiveness assessment and identification of indicators, it is not very likely that proposals such as "Consultation with other involved areas for setting up time schedule", or "Establishment of authorities and responsibilities for team members" will be put forward. On the other hand, it is quite likely that suggestions will be made for "Compliance with the overall time schedule", "Measurement of the real cost / planned cost ratio" or "Compliance with organizational goals for product financial return". Therefore, it can be seen that the research work, while succeeding in identifying aspects normally brought up whenever the assessment of effectiveness is concerned, at the same time succeeded in showing that some other aspects that are of concern to designers but do not always occur to discussers may be overlooked.

\subsection{Management actions}

The inspection of Table A.5 also reveals that the research results actually provide two types of information, both important for the continual improvement of the product design and development process, which are:

- Information relative to management actions for effectiveness assurance;

- Information relative to management actions for effectiveness evaluation.

A criterion for management actions classification was established according to concepts contained in the ISO 9000 (INTERNATIONAL..., 2005) standard for quality management systems.

Assurance actions are those indispensable to assure the efficiency of the design/development process, that is, to assure the best possible use of the available resources. 


\section{Using the Critical Incident Technique (CIT).}

2. Based on SERVQUAL dimensions.

3. Within SI. 4. Grouping of SI by
affinity.

5. With 10 statements/EF.

6. In order to increase precision and clarity of statements.

7. Incorporating findings and suggestions from test.

8. To respondent organizations.

9. Priority of statements/ effectiveness factor in each organization.

10. Priority of statements/ effectiveness factor in several organizations or industry using the Nominal Group Technique.

11. In assurance or evaluation management actions.

12. Proposal of a single effectiveness assessment index for the product design and development process.

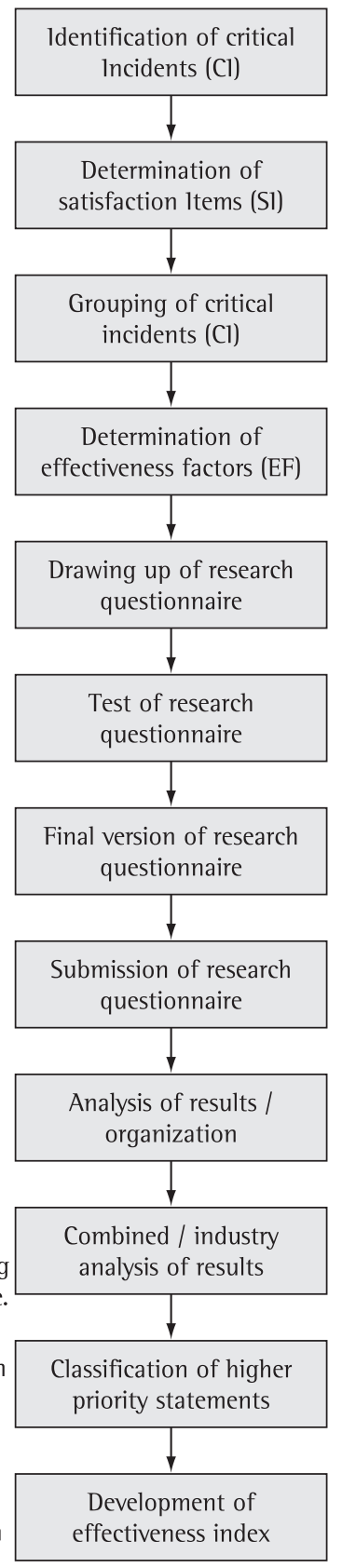

Figure 4. Proposed method for effectiveness assessment.

An example of a necessary assurance management action related to human resources is illustrated by statement 9 in Figure 3, since the absence of an adequate "Establishment of authorities and responsibilities for team members" may constitute an important factor leading to low levels of motivation among designers and very likely to a drop in the design/development process effectiveness.

Evaluation actions, on the other hand, are those aimed at verifying whether the desired objectives are being reached or not. In other words, whether the design/development process is effective or not. Those actions can be used to compose indicators and arrive at indexes capable of translating designers' concerns and opinions into figures needed to assess the effectiveness of the product design/development process.

Table A.6 shows indicators selected from those statements with evaluation management actions and ranked with high priority by the several designers interviewed in different organizations of the automotive industry, as previously shown in Table A.5. The selected indicators are also shown in Figure 5. Numbers within rectangles refer to questionnaire sections, or effectiveness factors, and to the respective statement of interest. Numbers outside rectangles, that is, $l_{1}$ to $l_{6}$, indicate indexes that express the mathematical content of the respective indicators.

\subsection{Effectiveness index}

As previously remarked, the structure of Figure 5 includes indices $\left(l_{1}\right.$ to $\left.l_{6}\right)$ relating to those indicators that reflect the common or "industry" perception of all interviewed designers. Such indices can be combined to provide a single index of continual improvement, which can be denominated Effectiveness Index $\left(1_{\mathrm{E}}\right)$, and that, according to the overall approach followed by this work, will simply be equal to:

$I_{E}=\frac{\sum_{i=1}^{n} I_{i}}{n}$

where:

- $\mathrm{l}_{\mathrm{i}}=$ index relating to industry indicator " $\mathrm{i}$ ";

- $\mathrm{i}=1,2 \ldots \mathrm{n}$;

In the present case, $n=6$.

It should be noted that expression (4) is sufficiently general to allow anyone responsible for effectiveness evaluation in a particular organizational context to choose those formulations considered more adequate to arrive at values for $l_{1}$ to $l_{6}$ (providing that all obtained values are expressed consistently, for instance from 0 to 100). Furthermore, it is also possible to add indices from other data sources - if this actually increases the level of information contained in $\mathrm{l}_{\mathrm{E}}$ - as well as to use $l_{E}$ in combination with broader indicator structures. What distinguishes $l_{E}$ is not its form, but rather its essence, that is, the fact that it reflects the designers' opinion through the selection of the indicators that originate it.

It is also considered that the main advantage of $\mathrm{I}_{\mathrm{E}}$ is to be a single index. Besides, if the criteria herein adopted are observed, it will always be an index 


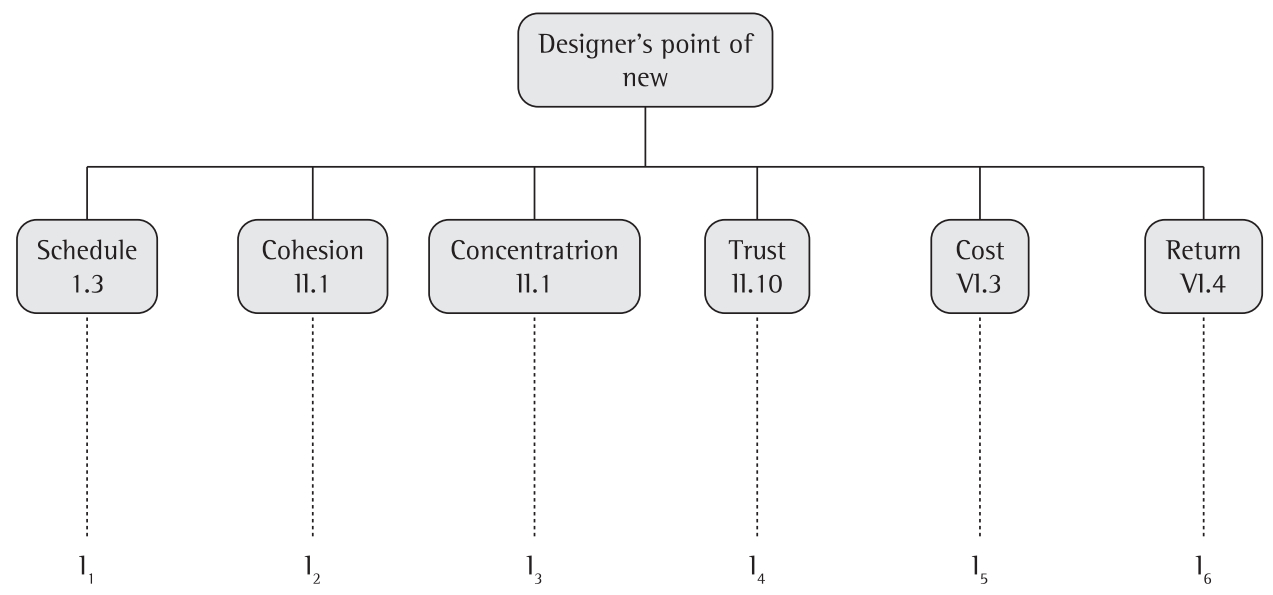

Figure 5. Structure of the effectiveness indicators for the design process in the automotive industry.

composed of a limited number of components. Thus, regardless of the degree of elaboration adopted by those in charge of effectiveness evaluation for each of the components $l_{1}$ to $l_{n}$, it is hoped that it will be relatively easy to arrive at a value for the effectiveness index. As a matter of fact, it is very likely that many organizations will already have indices that can be readily used or adapted as $1_{1}, 1_{5}$ and $1_{6}$. Therefore, it is believed that $1_{E}$ will be an attractive index for the evaluation of the product design/development process in design organizations.

When it is not possible - or desirable, when competition issues are involved, for instance - to carry out a research across the industry as done in the present work, but if it is possible to carry out the research across several units of the same organization, either in the same country, or in different countries, $\mathrm{l}_{\mathrm{E}}$ can be structured in much the same way as previously shown, by substituting corporate indices for the indices relating to industry indicators.

When it is only possible to carry out the research within a single organization, that is, when neither industry nor corporate indicators are available, it is still possible to use the proposed method considering only organizational indicators and, accordingly, the respective averages in lieu of the industry priority indices. This is, therefore, a general method, whose essential and differentiating characteristic lays in the fact that it derives from the perception of the designers themselves.

\section{Concluding remarks}

As previously stated, the objective of this work was basically to identify, from the designers' point of view, and employing well established methods in the fields of quality engineering and management, those factors that are deemed important to enable a given organization to assure and assess its capacity to continually improve the effectiveness of the product design/development process. It is believed that the results provided by both research phases, as well as the analysis work on the available data allow one to conclude that the intended objective has been attained.

It seems convenient to point out that although the preliminary phase was carried out consulting the opinions of designers involved with product design and development in different industries, it was possible, during the second phase, to identify effectiveness factors that were also very meaningful when a specific industry, i.e. the automotive industry, was considered.

In principle, the objective of the present work would have been attained by the identification and distinction between assurance and assessment actions for the effectiveness of the product design and development process. However, it is believed that such identification would have limited consequences without the adoption of the proposed effectiveness index. The use of such an index not only allows companies to individually assess their own product design and development processes, but also provides a useful means of comparison or benchmark with other similar processes. It is considered that the formulation of a single effectiveness index, which can be useful either for internal company assessments, or for external comparison purposes across corporations or industries, may be a significant contribution of the present work.

It is important to bear in mind, as previously mentioned, that statements listed in Table A.5 allow one to distinguish - when carrying out a joint analysis - those statements that represent a common concern for the whole industry from those constituting contingent or even permanent specific aspects of each company. 
Before closing, the authors would like to point out what they believe to be perhaps the most important contribution of the present work: the simplicity of the individual methods employed and, accordingly, of the general approach developed. This simplicity allows the proposed method to be readily and easily used in the everyday life of all product design and development organizations, exactly as intended from the very beginning.

\section{References}

AMERICAN SOCIETY FOR QUALITY - ASQ. Nominal group technique (NGT). 2004. Disponível em: <http://www.asq. org/learn-about-quality/idea-creation-tools/overview/ nominal-group.html>. Acesso em: 27 jan. 2011.

CAMINADA NETTO, A. Quality management in product design and development: a contribution to effectiveness evaluation. Thesis (Doctorate Degree in Mechanical Engineering)-University of São Paulo, 2006.

CAMINADA NETTO, A.; KAMINSKI, P. C. Assessing the quality of product design from the designer's point of view: the case of a global automotive supplier. In: INTERNATIONAL CONGRESS OF MECHANICAL ENGINEERING - COBEM, 19., 2007, Brasília, DF, Brazil. Anais...1 CD-ROM.

CAMINADA NETTO, A.; KAMINSKI, P. C. The voice of the product designer: a contribution to effectiveness evaluation in the automotive industry. Journal of Quality, 2006. Disponivel em: <http://www.iqa.org/journalofquality/recent.asp>.

DOBBIE, A. et al. Using a modified nominal group technique as a curriculum evaluation tool. Family Medicine, v. 36, n. 6, p. 402-406, 2004.

E.U.A. UNITED STATES ARMY. Action officer development course. 2006. Disponivel em: <http://www.cpol.army.mil/ library/train/courses/st7000d/toc.htm\#toc $>$. Acesso em: 27 de jan. 2006.

FlANAGAN, J. C. The critical incident technique. Psychological Bulletin, p. 327-358, 1954. PMid:13177800. http://dx.doi. org $/ 10.1037 /$ h0061470

HAYES, B. E. Measuring customer satisfaction. Milwaukee: $A S Q$ Quality Press, 1998.

INSTITUTO DA QUALIDADE AUTOMOTIVA - IQA. Presents ISO/ TS 16949, AIAG and VDA manuals. Disponível em: <http:// www.iqa.org.br>. Acesso em: 12 set. 2008.
INTERNATIONAL ORGANIZATION FOR STANDARDIZATION - ISO. ISO 9000:2005. Quality management systems - Fundamentals and vocabulary. Geneva, 2005.

INTERNATIONAL ORGANIZATION FOR STANDARDIZATION - ISO. ISO 9001:2008. Quality management systems - Requirements. Geneva, 2008.

LATOUR, B. Jamais fomos modernos. São Paulo, Brazil: Editora 34, 1994. 149 p. Nous n'avons jamais été modernes, Éditions La Découverte, Paris, 1991.

MICHIGAN STATE UNIVERSITY. Extension. Issue Identification Information 00005. 1994. Disponivel em: <http://web1. msue.msu.edu/msue/imp/modii/iii00005.html>. Acesso em: 27 de jan. 2011.

MIZUNO, S. The seven new QC tools. Cambridge, MA, EUA: Productivity Press, 1988. 322 p.

NAYATANI, Y. et al. The seven new QC tools. practical applications for managers. Tokyo: 3A Corporation, 1994. $181 \mathrm{p}$.

O’DONNELL, F. J.; DUFFY, A. H. B. Modelling design development performance. International Journal of Operations and Production Management, v. 22, n.11, p. 1198-1221, 2002. http://dx.doi.org/10.1108/01443570210450301

PARASURAMAN, A.; ZEITHAML, V. A.; BERRY, L. Balancing customer perceptions and expectations. New York: The Free Press, 1990.

SCHOLTES, P. R. The team handbook. Madison, Wl: Joiner Associates Inc. Management Consultants, 1988.

TAYLOR-POWELL, E. Program development \& evaluation. Collecting group data: Nominal group technique, Quick tips 3. Wisconsin University, 2002. Disponivel em: <http://www. uwex.edu/ces/pdande/resources/index.html>. Acesso em: 27 de jan. 2006.

THOMSON, D. S. et al. Managing value and quality in design. Building Research \& Information, v. 31, n.5, p. 334-345, 2003. http://dx.doi.org/10.1080/0961321032000087981

UMM STATISTICS. Biography e bibliography of J. W. Tuckey. Disponivel em: <http://www.mrs.umn.edu/ sungurea/ introstat/history/w98/Tukey.html>. Acesso em: 22 de jul. 2005.

\section{Acknowledgements}

The authors wish to express their deep gratitude to all of the designers who contributed their answers and to FAPESP (Fundação de Amparo à Pesquisa do Estado de São Paulo) for the financial support received.

\section{Proposta de um novo método para a avaliação da eficácia do processo de projeto e desenvolvimento do produto}

\section{Resumo}

Este artigo aborda a avaliação do processo de projeto do produto do ponto de vista do projetista de nível superior. Com base nos resultados de uma fase de pesquisa preliminar, elabora-se um questionário de pesquisa abrangente, que é submetido a um grupo de projetistas de nível superior do setor automotivo, compreendendo as operações brasileiras de duas grandes montadoras, de dois fornecedores diretos (Tier 1) das montadoras e de uma montadora de caminhões e ônibus. Os dados obtidos através das respostas ao questionário são compilados, apresentados e discutidos dentro de cada ambiente organizacional. Faz-se então uma análise conjunta, a fim de identificar aquelas ações gerenciais consideradas pelo setor automotivo como sendo mais importantes, tanto para garantir, quanto para avaliar a eficácia do processo de projeto e desenvolvimento do produto. Classifica-se essas ações em ações gerenciais de garantia e de avaliação de acordo com critérios fornecidos pelas normas ISO da qualidade. Finalmente, com base nas ações gerenciais de avaliação, define-se indicadores e se propõe um índice de eficácia único e flexível, que pode ser calculado utilizando-se, tanto dados organizacionais, quanto setoriais para fins de avaliação comparativa e benchmark.

Palavras-chave

Melhoria contínua. Método do incidente crítico. Eficácia. Projeto e desenvolvimento do produto. ServQual. 
Appendix 1. Questionnaire.

\section{Design realization}

This block is intended to take into consideration aspects relating to documentation and realization proper of the product design and development process. Please, tick the answer you consider to be the most adequate to describe the importance of each statement in relation to the continuous improvement of the product design/development process.

\begin{tabular}{|c|c|c|c|c|c|c|}
\hline \multicolumn{7}{|c|}{ Importance } \\
\hline & Vital & Very large & Large & Reazon-able & Small & Very small \\
\hline Statement & 6 & 5 & 4 & 3 & 2 & 1 \\
\hline Keep records of the entire design process history & $\square$ & $\square$ & $\square$ & $\square$ & $\square$ & $\square$ \\
\hline Have a data base of lessons learned & $\square$ & $\square$ & $\square$ & $\square$ & $\square$ & $\square$ \\
\hline Standardize all that can be standardized (calculations, drawings, etc.) & $\square$ & $\square$ & $\square$ & $\square$ & $\square$ & $\square$ \\
\hline Employ a specific design methodology & $\square$ & $\square$ & $\square$ & $\square$ & $\square$ & $\square$ \\
\hline Have the involvement of top management in the design effort & $\square$ & $\square$ & $\square$ & $\square$ & $\square$ & $\square$ \\
\hline Have the involvement of other areas in the design effort & $\square$ & $\square$ & $\square$ & $\square$ & $\square$ & $\square$ \\
\hline Control of completion dates for design phases & $\square$ & $\square$ & $\square$ & $\square$ & $\square$ & $\square$ \\
\hline Monitor design success indicators or criteria & $\square$ & $\square$ & $\square$ & $\square$ & $\square$ & $\square$ \\
\hline Establish authorities and responsibilities of design team members & $\square$ & $\square$ & $\square$ & $\square$ & $\square$ & $\square$ \\
\hline Program design activities & $\square$ & $\square$ & $\square$ & $\square$ & $\square$ & $\square$ \\
\hline
\end{tabular}

Table A.1. Design realization: summarized results.

\begin{tabular}{|c|c|c|c|c|c|c|c|c|c|c|}
\hline \multirow[t]{2}{*}{ Organization } & \multicolumn{2}{|c|}{ A } & \multicolumn{2}{|c|}{ B } & \multicolumn{2}{|c|}{ C } & \multicolumn{2}{|c|}{$X$} & \multicolumn{2}{|c|}{ Z } \\
\hline & Statement & Average & Statement & Average & Statement & Average & Statement & Average & Statement & Average \\
\hline $1^{\text {st }}$ & 10 & 5.57 & 9 & 5.38 & 5 & 4.86 & 10 & 5.26 & 9 & 5.13 \\
\hline $2^{\text {nd }}$ & 1 & 5.21 & 10 & 5.13 & 9 & 4.86 & 9 & 5.16 & 7 & 5.07 \\
\hline $3^{\text {rd }}$ & 9 & 5.21 & 5 & 5.08 & 10 & 4.71 & 7 & 5.05 & 10 & 4.80 \\
\hline $4^{\text {th }}$ & 7 & 5.07 & 7 & 5.04 & 1 & 4.64 & 5 & 4.95 & 3 & 4.73 \\
\hline $5^{\text {th }}$ & 2 & 5.00 & 8 & 5.00 & 2 & 4.64 & 8 & 4.95 & 4 & 4.67 \\
\hline $6^{\text {th }}$ & 3 & 4.93 & 2 & 4.88 & 3 & 4.57 & 4 & 4.84 & 5 & 4.67 \\
\hline $7^{\text {th }}$ & 6 & 4.93 & 3 & 4.83 & 6 & 4.57 & 1 & 4.68 & 1 & 4.60 \\
\hline $8^{\text {th }}$ & 5 & 4.86 & 6 & 4.79 & 8 & 4.54 & 3 & 4.68 & 8 & 4.60 \\
\hline $9^{\text {th }}$ & 8 & 4.64 & 1 & 4.71 & 7 & 4.36 & 2 & 4.63 & 2 & 4.40 \\
\hline $10^{\text {th }}$ & 4 & 4.57 & 4 & 4.58 & 4 & 4.14 & 6 & 4.63 & 6 & 4.13 \\
\hline
\end{tabular}

Table A.2. Design realization: combined results.

\begin{tabular}{|c|c|c|c|c|c|c|c|c|c|c|}
\hline Statement & 1 & 2 & 3 & 4 & 5 & 6 & 7 & 8 & 9 & 10 \\
\hline $1^{\text {st }}$ & & & & & C & & & & $\mathrm{BZC}$ & $\mathrm{AX}$ \\
\hline $2^{\text {nd }}$ & A & & & & & & $\mathrm{Z}$ & & $\mathrm{AX}$ & B \\
\hline $3^{\text {rd }}$ & & & & & B & & $X$ & & & $\mathrm{ZC}$ \\
\hline $4^{\text {th }}$ & C & C & $\mathrm{Z}$ & & $x$ & & $\mathrm{AB}$ & $x$ & & \\
\hline $5^{\text {th }}$ & & A & & $\mathrm{Z}$ & $\mathrm{Z}$ & & & B & & \\
\hline $6^{\text {th }}$ & & B & $A C$ & $x$ & & $A C$ & & & & \\
\hline $7^{\text {th }}$ & $X Z$ & & $\mathrm{BX}$ & & & & & $\mathrm{Z}$ & & \\
\hline $8^{\text {th }}$ & & & & & $A$ & B & & C & & \\
\hline $9^{\text {th }}$ & B & $X Z$ & & & & $X$ & $C$ & A & & \\
\hline $10^{\text {th }}$ & & & & $A B C$ & & $\mathrm{Z}$ & & & & \\
\hline High & 2 & 4 & 4 & 5 & 1 & 6 & 2 & 4 & 1 & 1 \\
\hline Low & 9 & 9 & 7 & 10 & 8 & 10 & 9 & 9 & 2 & 3 \\
\hline RPA & 7 & 5 & 3 & 5 & 7 & 4 & 7 & 5 & 1 & 2 \\
\hline
\end{tabular}


Table A.3. Design preparation: sum of averages.

\begin{tabular}{|c|c|c|c|c|c|c|}
\hline Organization & A & B & $X$ & Z & C & \\
\hline Statement & Average & Average & Average & Average & Average & Sum \\
\hline 1. Consult other involved areas for drawing up timetable. & 5.50 & 5.54 & 5.63 & 5.47 & 5.36 & 27.50 \\
\hline 2. Comply with timetable for each design phase. & 5.00 & 4.88 & 4.79 & 4.87 & 4.50 & 24.04 \\
\hline 3. Comply with timetable as a whole. & 5.36 & 5.13 & 5.37 & 5.40 & 5.14 & 26.40 \\
\hline 4. Have specific budget for design and development. & 4.62 & 4.13 & 4.42 & 4.86 & 4.86 & 22.89 \\
\hline 5. Consult other involved areas for identification of costs. & 5.00 & 4.75 & 4.74 & 4.87 & 5.15 & 24.51 \\
\hline 6. Keep within design budget. & 4.71 & 4.70 & 5.00 & 4.87 & 4.64 & 23.52 \\
\hline 7. Have last-generation computational resources. & 4.86 & 4.17 & 3.47 & 4.20 & 3.93 & 20.63 \\
\hline 8. Have means for concept validation (labs, prototypes, etc.). & 5.79 & 4.79 & 5.16 & 5.27 & 5.14 & 26.15 \\
\hline 9. Have access to manufacturing resources. & 4.71 & 4.79 & 4.37 & 4.33 & 4.31 & 22.51 \\
\hline \multirow[t]{2}{*}{ 10. Define quantitative objectives. } & 4.71 & 4.65 & 4.79 & 4.67 & 4.58 & 23.40 \\
\hline & \multicolumn{5}{|c|}{ Total sum } & 241.55 \\
\hline
\end{tabular}

Table A.4. Design realization: priority index.

\begin{tabular}{|c|c|c|c|c|c|c|c|c|c|c|}
\hline \multirow{2}{*}{ Grade } & \multicolumn{10}{|c|}{ Statement } \\
\hline & 1 & 2 & 3 & 4 & 5 & 6 & 7 & 8 & 9 & 10 \\
\hline 10 & & & & & 10 & & & & 30 & 20 \\
\hline 9 & 9 & & & & & & 9 & & 18 & 9 \\
\hline 8 & & & & & 8 & & 8 & & & 16 \\
\hline 7 & 7 & 7 & 7 & & 7 & & 14 & 7 & & \\
\hline 6 & & 6 & & 6 & 6 & & & 6 & & \\
\hline 5 & & 5 & 10 & 5 & & 10 & & & & \\
\hline 4 & 8 & & 8 & & & & & 4 & & \\
\hline 3 & & & & & 3 & 3 & & 3 & & \\
\hline 2 & 2 & 4 & & & & 2 & 2 & 2 & & \\
\hline 1 & & & & 3 & & 1 & & & & \\
\hline $\mathrm{S}_{\mathrm{j}}$ & 26 & 22 & 25 & 14 & 34 & 16 & 33 & 22 & 48 & 45 \\
\hline $\mathrm{Pl}_{j}$ & 9 & 8 & 9 & 5 & 12 & 6 & 12 & 8 & 17 & 16 \\
\hline
\end{tabular}

Table A.5 - Selected statements for the adoption of management actions.

\begin{tabular}{|c|c|c|c|}
\hline Section & Statement & $\mathrm{Pi}_{j}$ & MA \\
\hline \multirow[t]{3}{*}{ 1. Design preparation } & 1. Consult other involved areas for drawing up timetable & 17 & A \\
\hline & 3. Comply with timetable as a whole & 15 & $\mathrm{E}$ \\
\hline & 8. Have means for concept validation (labs; prototypes; etc.) & 14 & A \\
\hline \multirow[t]{3}{*}{ 11. Organizational environment } & 1. Have a cohesive working team & 16 & $\mathrm{E}$ \\
\hline & 8. Have working conditions that assure concentration on design realization & 15 & E \\
\hline & 10. Have mutual trust between company and employees & 15 & $\mathrm{E}$ \\
\hline \multirow[t]{3}{*}{ 111. Information and knowledge } & 1. Assess product market viability vis-à-vis the competition & 17 & A \\
\hline & 2. Review client / market requirements & 15 & A \\
\hline & 4. Identify design potential risks & 14 & A \\
\hline \multirow[t]{3}{*}{ IV. Technical personnel } & 2. Have members with practical experience in the design team & 16 & A \\
\hline & 5. Be concerned with the maintenance of technical capacity & 14 & A \\
\hline & 7. Have a leader in the design team & 15 & A \\
\hline \multirow[t]{3}{*}{ V. Design realization } & 5. Have the involvement of top management in the design effort & 12 & A \\
\hline & 9. Establish authorities and responsibilities of design team members & 17 & A \\
\hline & 10. Program design activities & 16 & A \\
\hline \multirow[t]{3}{*}{ Vl. Product success } & 3. Measure the real cost to planned cost ratio for the design & 14 & E \\
\hline & 4. Measure the real cost to planned cost ratio for the design & 18 & E \\
\hline & 5. Define a committed-to-development supplier base & 15 & A \\
\hline
\end{tabular}

MA: management action; A: assurance; E: evaluation.

Table A.6. Effectiveness indicators for the product design and development process in the automotive industry.

\begin{tabular}{cccccc}
\hline Table A.5 & Indicator & Index & Table A.5 & Indicator \\
\hline 1.3 & Compliance with the overall time schedule & $\mathrm{l}_{1}$ & 11.10 & Degree of mutual trust between company and employees & $\mathrm{l}_{4}$ \\
11.1 & Degree of cohesion in design team & $\mathrm{l}_{2}$ & $\mathrm{Vl} .3$ & Real cost / planned cost ratio \\
11.8 & Degree of concentration on design realization & $\mathrm{l}_{3}$ & $\mathrm{Vl} .4$ & Product financial return \\
\hline
\end{tabular}

